\title{
Папков С.А. \\ Образование алтайской автономии и первые решения ее организаторов
}

Институт истории СО РАН

(Россия, Новосибирск)

doi: 10.18411/trnio-10-2021-159

\section{Аннотация}

В публикации содержатся новые материалы об образовании первой национальной автономии в Сибири, позволяющие глубже оценивать политические условия и потребность выделения Горного Алтая в самостоятельную область, несмотря на малочисленность коренного населения и неразвитость экономики региона. Автор полемизирует со взглядами тех исследователей, которые не находят серьезных социальных и политических причин для образования национальной автономии алтайского народа в начале 1920-х годов. Подобные взгляды, полагает автор, носят умозрительный характер и опровергаются новыми архивными документами. В статье приводится серия оригинальных материалов об утверждении первого состава облревкома области и распределении обязанностей между его членами, о формировании территориальных границ автономии, решении вопросов телеграфной связи, транспорта, имущественных отношений, создании аппарата управления и других оперативных проблем, необходимых для существования области. Особое место в публикации занимает информационное письмо председателя облревкома, характеризующее действия специальных воинских отрядов, присланных для подавления восстания местного населения.

Ключевые слова: автономия, Горный Алтай, ревком, управление, бандитизм, подавление восстаний, части особого назначения.

\section{Abstract}

The publication contains new materials about the formation of the first national autonomy in Siberia. A series of original documents on the approval of the first composition of the local revolutionary committee and the distribution of duties of its members is given. The author disputes the views of those researchers who do not find serious social and political reasons for the formation of the national autonomy of the Altaians in the early 1920s. Such views, according to the author, are speculative and refuted by new archival documents. The presented materials convince us that the desire to create autonomy was dictated by objective conditions. One of the main reasons was the desire and hope of the Altaians to put an end to the oppression by the ruling administration and its agents. The article provides a series of original materials on the approval of the first composition of the regional committee of the region and the distribution of responsibilities between its members, on the formation of the territorial boundaries of the autonomy, solving issues of telegraph communication, transport, property relations, creating a management apparatus and other operational problems necessary for the existence of the region. Their content clearly indicates the state priorities set for the autonomy: the establishment of the local economy and the implementation of fiscal procedures. A special place in the publication is occupied by the information letter of the chairman of the revkom about the actions of special military detachments sent to suppress the uprising of the local population.

Keywords: autonomy, Gorny Altai, revkom, management, banditry, suppression of uprisings, special troops.

История возникновения Ойротской (Горно-Алтайской) автономной области детально описана в современной научной литературе. В многочисленных публикациях на эту тему проанализированы причины, побудившие советское руководство создать автономию 
алтайцев, освещена роль национальных лидеров, дана оценка политическим, социальноэкономическим и культурным последствиям выделения региона в автономию.

Между тем, некоторые материалы из ранней истории области (затем - республики) остаются малоизвестными в историографии, сохраняя несомненный научный интерес. В данной публикации впервые представлены документы о первых заседаниях и решениях органа управления областью - облревкома Ойротии, - целью которых являлась организация основных учреждений, выбор административного центра, налаживание связи и хозяйственной жизни, а также утверждение круга руководящих работников Горного Алтая.

Как исторический источник, эти документы имеют принципиальное значение в нескольких аспектах. Прежде всего, они воспроизводят последовательность мероприятий в строительстве первой в Сибири национальной автономии и дают весь перечень главных действующих лиц, вовлеченных в этот процесс на его ранней стадии. Однако значительно важнее другая сторона этих материалов. На их основе можно судить о том, что процедура образования новой области и борьба за определение ее границ протекали в такой необычной социально-политической обстановке, которая, по существу, и продиктовала необходимость предоставления алтайскому анклаву статуса автономии.

В современной научной литературе можно встретить утверждения, что создание автономии алтайцев практически не имело глубинных оснований и серьезных предпосылок, что оно не опиралось на волю самого народа, не диктовалось его коренными интересами, а являлось лишь уступкой амбициям малочисленной группы национальной интеллигенции, рассчитывавшей в обстановке революционного хаоса получить некоторые привилегии для своего народа. Так, например, автор одной из публикаций, М. В. Белозерова, проанализировав итоги полемики по «алтайскому вопросу» в большевистских кругах в начале 1920-х годов, формулирует следующий вывод: «...каких-либо оснований, экономических или этнических, для выделения автономии на территории Горного Алтая, в сущности, не было. (...) Основным аргументом в ее пользу был, на наш взгляд, националистический...».

Нельзя сказать, чтобы описанные в нем методы «усмирения» населения в виде откровенных грабежей использовались как спланированный, заранее рассчитанный акт центрального правительства. Вполне очевидно, что жестокие действия обеих сторон диктовались самими условиями гражданской войны. Но здесь речь идет о чисто карательной операции и мародерстве, жертвами которых являлось именно гражданское население. Поэтому акции карателей из частей особого назначения (ЧОН) и Красной Армии неизбежно становились для сторонников автономии еще одним убедительным аргументом своей правоты. Обретение статуса автономии ее инициаторы не могли рассматривать иначе как средство защиты и спасения малого народа. А требование обуздать мародеров, выступающих в роли «борцов с бандитизмом», включалось в повестку дня как одна из первоочередных задач (см. параграф 3 прокола № 6).

К этому автор также добавляет: «Ни предшествующие исследования, ни источники не свидетельствуют о том, что это было желание всего алтайского народа. (...) ...данные идеи сформировались в среде национальной интеллигенции до Октябрьской революции 1917 г., близкой к сибирской областникам... Используя националистические настроения части алтайцев, политику большевиков, направленную на реализацию самоопределения наций, ...им [советским руководителям Ойротии - С.П.] удалось реализовать идею автономии...» [15. C. 65].

Подобные абсолютно не корректные во многих смыслах и неприемлемые утверждения с обвинениями народу Горного Алтая в «националистических настроениях», проистекают из явного смешения понятий. Не стоит спорить с тем, что «оснований, экономических или этнических, для выделения автономии не было». Проблема состояла 
вовсе не в этих «основаниях». Такие «основания» для выделения этносов в национальную территорию вообще не существуют сами по себе. Это была острая политическая проблема, которая со временем приобрела форму требований национального самоопределения. Публичное выражение и стремление к автономии, на которой настаивали первые алтайские интеллигенты (наряду, кстати, с русскими просветителями), были продуктом многолетнего притеснения малого народа, игнорирования его законных интересов и традиций. Ранняя советская власть здесь также не отличалась особой деликатностью. Именно об этом ясно свидетельствует документ № 3 - наиболее выразительный из всех остальных. Этот документ особенной силы. Он отчетливо показывает какую роль играло большевистское руководство в данном регионе и какие методы оно применяло для решения части вопросов в отношении алтайского этноса. Документ был подготовлен председателем облревкома Н.Ф. Ивановым и адресован остальным членам создаваемой автономии в самый критический момент, когда необходимо было спасать сотни людей от нашествия отрядов ЧОН и Красной армии и не допустить «окончательного разорения населения области».

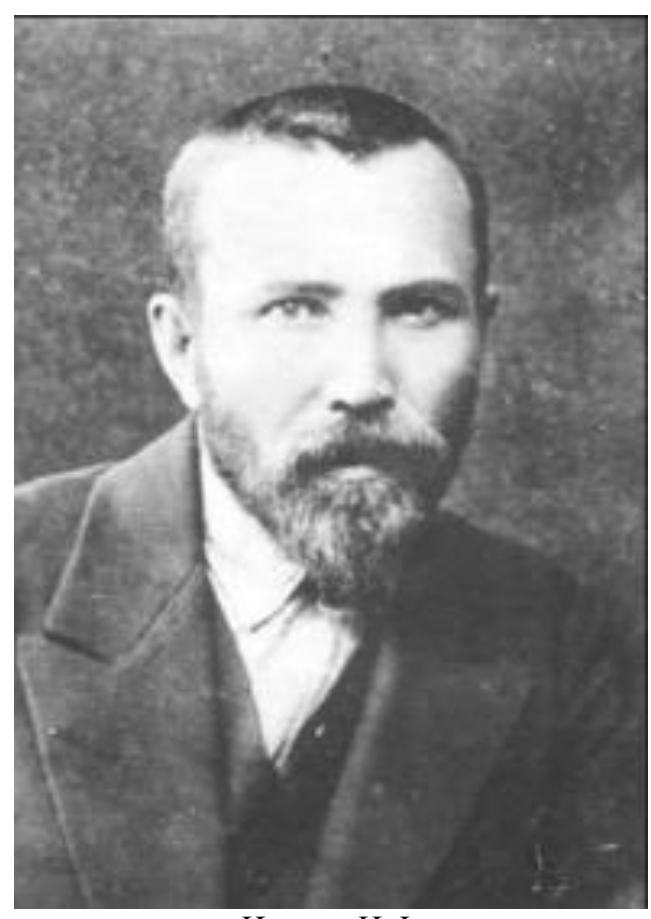

Иванов Н.Ф.

Показательно здесь и то, что автор «Обращения», председатель ревкома Никита Иванов, осторожно упоминает имя лишь одного человека, причастного к военным преступлениям в Горном Алтае. Это - командир «истребительного отряда» ЧОН Иван Долгих, с действиями которого связан захват «десятков бандитских семей» и различных «трофеев и скота» с теми последствиями, что часть населения «обобрали до нитки, не оставив ни собаки и выселив из указанного района». Отряд этого начальника именно так и назывался - «истребительный», поскольку его задачей являлось «истребление бандитов» вместе с их семьями, отчаянно сопротивлявшихся разного рода поборам и «экспроприациям». И.И. Долгих вообще очень известная личность в советской истории Алтая. За «героизм» в подавлении противников советской власти в 1922 г. с применением массовых погромов в алтайских поселениях и стойбищах он был удостоен ордена «Красного Знамени». Однако не меньше подобных «заслуг» у него было и в другой кризисный период при проведении коллективизации. Для исполнения новых оперативных большевистских заданий в Горном Алтае Долгих и здесь оказался наиболее подходящей кандидатурой. Вот как он сам описывал собственную роль в этих событиях: 


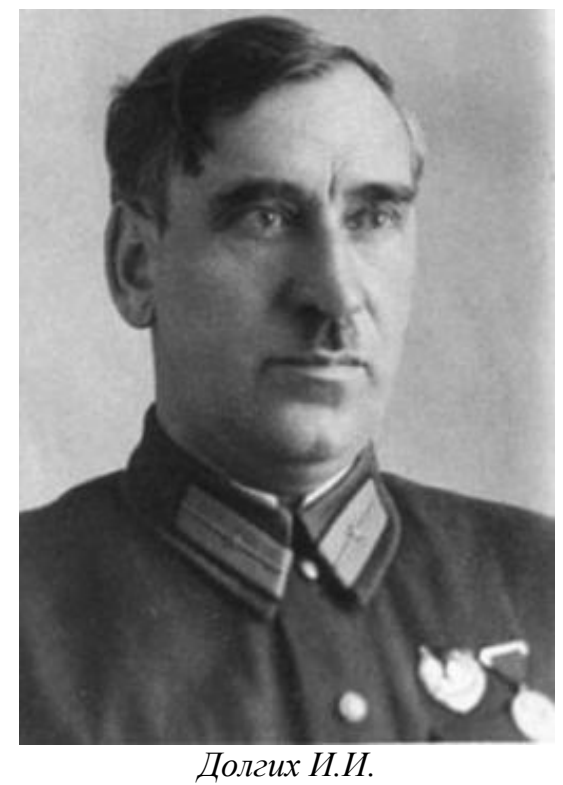

«Когда началось Алтайское восстание в 1930 году, т. Эйхе дал телеграмму окружкому послать Долгих на его подавление. Я лежал больной гриппом, только что приехав из Чульмской тайги, [где] по поручению окружной парторганизации вывозил хлеб. После телеграммы т. Эйхе я встал с постели и через 6 часов уже был в Бийске и дальше - 8 Ойротии. Я принял все от меня зависящие меры, развил всю свою энергию с тем, чтобы оправдать доверие, с согласия партийных организаций собрал до 400 человек бывш. партизан, отбросил все разложившееся, ненадежное, потерявшее ценность, и может быть жестко (чего мы боялись с т. Гариным [зам. начальника ОГПУ Сибкрая - С.П.]) восстание подавили» [ Гос. архив Новосибирской области (ГАНО). Ф. П-8. Оп. 1. Д. 1041а. Л. 119-120].

Часть не самых шокирующих «подвигов» этого «героя» в конечном счете вошла в советскую мифологию и была зафиксирована в книге «Гордость Барнаула», изданной в 1980 году. В последующий период Долгих служил начальником Барнаульской тюрьмы и милиции округа, затем в системе ГУГАГа в качестве начальника лагерей НКВД-МВД в Сибири, на Урале и в Московской области. В 1950 году он вышел на пенсию в звании полковника и умер в Москве в 1956-м.

Имена остальных участников событий, связанных с образованием Горно-Алтайской области - Н.Ф. Иванова, С.-С. Конзычакова, Л.А. Папардэ, П.Я. Гордиенко, П.А. Строева, И.С. Алагызова и других руководителей первого состава ревкома в советскую эпоху были преданы забвению. Почти все они подверглись казни или исчезли в лагерях ГУЛАГа, и лишь в годы перестройки память о них была восстановлена, а их вклад в создание первой национальной автономии в Сибири получил заслуженную историческую оценку.

Документы Ойротского облревкома публикуются в хронологическом порядке и в том виде, в каком формировались в делопроизводстве ревкома, с сохранением структуры протоколов, особенностей орфографии и терминологии, принятой в тот период.

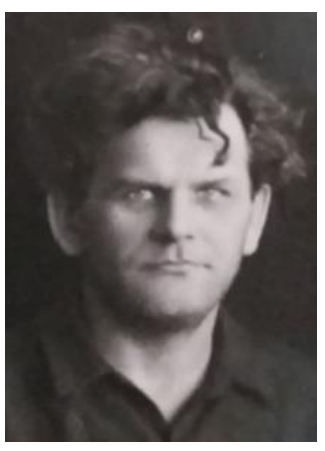

Папардэ Л.А.

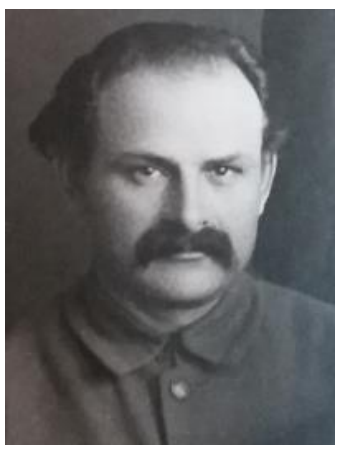

Гордиенко П.Я

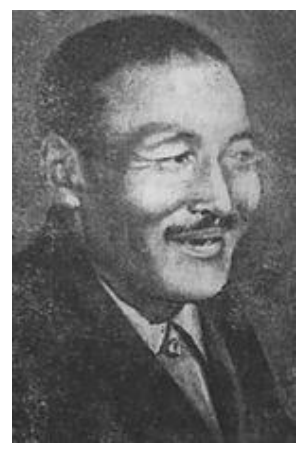

Строев П. А.

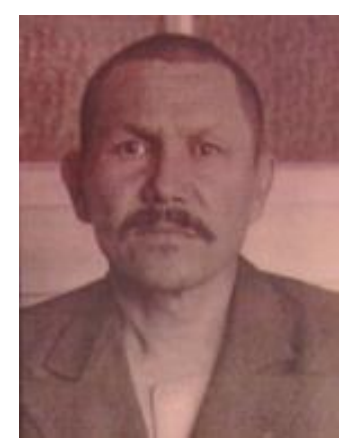

Алагызов И.С. 


\section{Приложение.}

\section{П РОТ ОКОЛ № 1}

заседания Революционного Комитета Ойротской Автономной Области.

3 августа 1922 г.

ПРИСУТСТВУЮТ: т.т. Председатель Революционного комитета тов.

ИВАНОВ, члены ПАПАРДЭ, ЧУСОВ и

Представитель Сибревкома ГОРДИЕНКО.

СЛУШАЛИ: $\S 1$ Постановление ВЦИК от 1 июня с.г. о выделении Ойротской Автономной Области.

ПОСТАНОВИЛИ: $\S 1$. В целях пирокого ознакомления населения с вопросом декретирования ВЦИК Ойротской Автономной Области, к моменту передачи управления Облревкому выпуспить обращ ение разъясняюще значение этого акта.

Составление обращ ения поручить т.т. ИВАНОВУ и ГОРДИЕНКО.

СЛУШАЛИ: $\S 2$. О конструировании Облревкома и начале работы.

ПОСТАНОВИЛИ: $\S 2$. Заслушав постановление Сибревкома от 22-го марта с.г. за № 800 о назначении Облревкома в составе т.т. ИВАНОВА, САРЫ-СЕП-КОНЗЬЧАКОВА, СТРОЕВА, ПАПАРДЭ И ЧУСОВА.

ПОСТАНОВИЛИ: до начала Управления Областью поскольку в период передачи территории сохраняет за собой административное руководство Алтгубисполком и на месте Горно-Алтайский Уисполком, но ввиду того, что текущими условиями выявляется потребность начала работ Облревкома - наличному составу Облревкома начать с 3 августа с.г. предварительную работу, назначив для технических целей временно секретарем Облревкома тов. МАЛКОВА.

СЛУШАЛИ: § 3. Постановление Губисполкома от 6-го июля с.г. за № 63 и протоколы заседаний Административной п/комиссии Алтубисполкома от 1-го июля с.г. за № 4 и от 3 го июля за № 5 о проведении границ между Алтгубернией и Ойротской Автономной Областью.

ПОСТАНОВИЛИ: § 3. Для фактической передачи волостей отходящих в Алтгубернию и приема волостей Бийского уезда, включаемьх в пределы территории Ойротской Автономной Области, а также по вопросу получения и передачи предприятий и имущества Отделов Бийского и Горно-Алтайского Уисполкомов - уполномоченным от Облревкома назначается тов. ПОДГОРНОВ.

СЛУШАЛИ: § 4. О назначении комиссии по распределению квартир для Облучреждений и сотрудников в с. Улале.

ПОСТАНОВИЛИ: $\S 4$. Комиссию назначить в составе т.т. ТОЛМАЧЕВА, ВАСИЛЬЕВА и КОМКИНА.

Подлинный за надлежащими подписями.

Верно: секретарь МАЛКОВ (подпись). 


\section{П РОТ ОКОЛ № 4}

Торжественного Заседания Революционного Комитета Ойротской Автономной Области. 18 августа 1922 г.

На заседании ПРИСУТСТВУЮТ: Предоблревкома т. ИВАНОВ, члены:

ПАПАРДЭ, СТРОЕВ, ЧУСОВ, Представитель Сибревкома

ГОРДИЕНКО, Заведьвающие Отделами, п/отделами,

сотрудники учреждений, делегаты Съездов, работники

Юстиции, секретари Волпарткомов и Комитетов

Взаимопомощи при переполненном публикой зале.

Заседание открывает тов. ИВАНОВ.

/Оркестр исполняет ИНТЕРНАЦИОНАЛ/.

Слово предоставляется тов. ПАПАРДЭ, которьй в пространной речи изложив ход революционной борьбы трудящихся за свое освобождение, потерю лучших борцов предлагает почтить память вставанием.

/Присутствующие встают, оркестр исполняет «ПОХОРОННЫЙ МАРШ» /

Для приветствия слово предоставляется представителю Сибревкома и Сиббюро ЦК РКП при Ойротском Облревкоме.

Тов. ГОРДИЕНКО в своей краткой горячей речи приветствует от имени Сибирского Революционного Комитета и Сиббюро ЦК РКП трудящихся Ойротской области в лище Революционного Комитета и присутствующих, высказывает пожелания, чтобы выдвинутый Областной орган вновь народившейся единицы действительно оправдал надежды центра, доведя отсталые народности до политического и экономического благосостояния.

/Бурные аплодисменты/ .

Место председателя занимает тов. ПАПАРДЭ.

Слово предоставля ется тов. ИВАНОВУ.

Объявляя присутствующим о вступлении Революционного Комитета в управление Областью, докладчик подробно останавливается на истории Ойротских народностей, их разбросанности, авантюре Колчака и Каракорума, благодаря которым несознательные отсталые калмьки явились жертвою контр-революции поддерживающими бандитизм и увлеченные в национальную вражду. Излагая процесс выделения Области, докладчик предлагает Революционному Комитету принять обращение к трудящимся Области, разъясняющее значение акта выделения и первоочередные задачи /читает/.

/Обрап ение единогласно принимается/.

Тов. ГОРДИЕНКО вносит предложение послать приветствие красным бойцам борющимся с бандитизмом на Алтае и приветственные телеграммы ВЦИК и СНК.

/Предложение под бурные аплодисменты присутствующих Облревкома принимается/. Заседание объявля ется закрытым.

Предолбревкома и предзаседания ИВАНОВ

Секретарь МАЛКОВ

Верно: секретарь Малков (подпись). 
Информация председателя облревкома Н. Ф. Иванова для членов президиума ревкома о положении в области

$$
\text { ДОКЛАДНАЯ ЗАПИСКА }
$$

Президиуму Революционного Комитета Ойротской Автономной области

За все время ликвидации бандитизма в Горном Алтае со стороны действующих воинских частей наблюдаются следующие ненормальные поступки по отнопению населения: воинские части в момент очистки того или другого района от бандитов отбивают у последних скот и имущество награбленное ими у населения. Иногда белобандитские пайки занимают целые районы, держа население данного района под постоянной угрозой, и под напором напих частей, при отступлении, банды силой оружия угоняют население, а в особенности кочевое, вглубь занимаемого им района со всеми пожитками. Таким способом банды ограбляя население создают себе продовольственные базы и являются господами положения цельг районов, терроризируя население.

Когда напи воинские части очищают от бандитов какой-либо из этих районов, отбивают у них имущество и скот, считают таковое военньми трофеями, тогда как это имущество по существу принадлежит населению.

По закону гражданской войны надо бы полагать, что отбитое у грабителей имущ ество подлежит возврату его владельцам, однако воинские части считают его своей законной добычей.

Кроме того, воинские части считают военной трофеей* не только отбитое у бандитов имущество, но при занятии того или иного населенного пункта занимаемого раньпе бандитами забирают непосредственно у населения все имущ ество и скот и также считают его военньми трофеями. Такие действия военчастей уже никак нельзя признать правильными. Укажу на следующие факты: 185 полк 62-й бригады 21 дивизии, заняв поселок Хабаровку Онгудайской волости и ряд других населенньх пунктов, забрал там все имущ ество вплоть до земледельческих орудий. Выходя из пределов Алтая, указанньй полк вывез целые обозы с разным имуществом принадлежащим населению Горного Алтая, которое по сути распродавалось воинскими частями и таким способом благосостояние края в корне подрывалось подобными действиями воинских частей.

Первьм Семипалатинским полком во время его пребьвания в Уймонском крае изьяты у населения сотни лопадей, в том числе больпинство попали самые наилучшие производители. А что значит лишь домохозяина быть может последней рабочей лопади? это равносильно обречь его с семейством на голодное существование. Или взять у домохозяина производителя? - это значит обречь на гибель все его стадо молодьх подростков, которые разбредутся и будут истреблены хищными зверями.

Несмотря на предложение политтрупш, ездившей тогда по Уймонскому краю, возвратить взятых рабочих лопадей, а в особенности производителей, 1-й Семипалатинский полк не только не возвратил этих лопадей населению, а еше добавил к ним, забрав у населения остатки, и ушел из Уймонского края, оставляя своей добычей все взятое у населения. Такой поступок военчастей население никак не может иначе считать как грабежом. Противникам же Советской власти дается повод липний раз клеветать на Совласть, показывая наглядно на беззаконные дейстия Правительственньх войск.

За последнее время Уймонской группой, действующей против бандитов в районе, принадлежащ ем к Аргутам, т. ДОЛГИХ доносит по своей линии, что очищ ен такой-то район, захвачено столько-то бандитских семей, захвачены такие-то трофеи, столько-то скота и т.д. и т.п. Между прочим, мне доносят, что в момент занятия нашими частями Приаргутского района последними захвачено несколько десятков семейств кочевого населения, которьх воинские части обобрали до нитки, не оставив им ни собаки, и выселили их из указанного района в тыл. Обобранное население проживает сейчас по русским селам Уймонского района, питаясь подаяниями населения и, видя перед собой угрозу голодной смерти, боятся возбуждать ходатайства о возвращ ении им имущ ества и скота. 
Секретарь Катандинского Волостного Партийного Комитета РКП от имени указанньг семей подал мне записку, в которой рисует положение выселенных инородцев и просит вернуть им скот имущ ество взятое воинскими частями.

Укажу на следующее: местность Аргут еше никогда не занималась Советскими войсками и туда по всей вероятности стекалась масса кочевого населения еще в дни партизанского движения против Колчака. Обькновенно полудикое кочевое население, дабы укрыться от пальной пули, искало убежище, где бы можно было избегнуть последствий гражданской войны. Кроме того, агитация противников Советской власти, которая сводится к усиленному распространению среди кочевого населения о различных зверствах "красных", запугивает не только полудикие племена, а наводит страх и на более развитые элементы. Произвольные действия напих воинских частей еще более подливают масла в огонь, и вполне естественно, что население бежит куда попало - прячась в непроходимые трущобы, спасая свою пккру.

Если в дальнейпем военные будут производить свой метод, какой проводился и проводится по сие время, то со взятием Аргута сотни семейств будут обобраны дочиста и обречены на голодную смерть, а воинские части, забравпи имущество у населения, будут считать все взятое военными трофеями. Десятки хозяйств будут разорены, и без того разрупенное хозяйство Соввласти невозможно будет восстановить.

Принимая во внимание изложенное и дабы сохранить от окончательного разорения населения Области, Президиуму Ревкома надлежит положить предел всем тем ненормальностям, какие наблюдались и наблюдаются до сих пор, поэтому я считаю необходимым приня ть следующие мерыг

1/ Просить Сибревком разрешить создать Специальные Комиссии при действующих частях под председательспвом Представителя Сибревкома, которые должны будут брать на учет все военные трофеи и на месте выяснять принадлежность таковых. И если отбитое военньми от бандитов имущество окажется принадлежащим населению, то возвращать таковое владельцам. Комиссия должна будет устанавливать было ли это имущество бандитами ограблено у населения, и если окажется, что население само добровольно давало бандитам то или иное имущество, то таковое безусловно подлежит конфискации и, как имущество данной Области, должно передаваться Комитетам Взаимопомощи для восстановления хозяйств разоренньг бандитами, и добровольно помогавпие бандитам должны привлекаться к ответственности, и эти мероприятия, можно с уверенностью сказать, помогут делу ликвидации бандитизма и раз навсегда искоренят красный бандитизм среди воинских частей, который наблюдался и наблюдается среди последних.

2/ Необходимо возбудить ходатайство перед Сибревкомом об изъятии из 1-го Семипалатинского полка ЧОН всех рабочих лоп адей принадлежащих населению Ойротской Автономной Области, взятьх у населения в бытность частей Семполка в Уймонском крае и вернуть таковьх населению Уймонского края, ибо эти лопади Семполком даже не были отбиты у бандитов, а забирались у населения.

3/ Просить Сибревком положить конец всем беззакониям творимьм воинскими частями, сделав по военной линии надлежащие распоряжения, которьпи впредь руководствовались бы как военные, так и гражданские организации в деле ликвидации бандитизма, успокоения населения и укрепления Советской власти в Области.

С момента выделения Ойротской автономной Области как единицы, находящейся на окраине Республики, необходимо твердо установить порядок и законность т.к. родственные племена Ойротскому народу, находящиеся в пограничном районе Монголии, будут судить о Советской власти только сейчас и этот момент необходимо использовать в интересах Совреспублики.

Председатель ревкома

Ойротской Автообласти ИВАНОВ (подпись)

23 августа 1922 года. 


\section{П Р О Т О К Л № 6}

Внеочередного заседания Ой ротского Областного Революционного Комитета

24 августа 1922 года.

ПРИСУТСТВУЮТ: Предоблревкома т. ИВАНОВ, члены: ЧУСОВ, ПАПАРДЭ, Представитель Сибревкома тов. ГОРДИЕНКО, Секретарь МАЛКОВ и Представитель Связи т.т. ЩЕГЛОВ и КУЗНЕЦОВ

\section{СЛУШАЛИ:}

$\S$ 1. Доклад тов. КУЗНЕЦОВА о назначении его заведывающим Областной П/Телеграфной Конторой в с. Улале. Из доклада и переговоров по прямому проводу тов. КУЗНЕЦОВА выясняется, что ему поручено совместно c Завконторой Алтайска выделить необходимое количество почтовых работников для Областной ПочтовоТелеграфной Конторы, каковых нужно не менее 17 человек, и принять район с 1 сен тября.

Т ов. ЩЕГЛОВ, дополняя доклад, отмечает, что из Алтайской Поч.-Тел. Конторы можно выделить не более 3-4 человек и в Области во всех отделениях работники останутся с весьма небольшой подготовкой и опытностью.

Тов. КУЗНЕЦОВ предлагает Революционному Комитету сейчас же сказать об его утверждении в должности Заведывающего Областной Конторой, заявляя, что он хочет заведывать только Областной Конторой и никуда больше не поедет и другие должности исполнять не будет. Кроме того говорит, что у меня семейство 7 человек, огород и пр. и мне нужно устроиться.

$\S 2$. О переводе Областных учреждений в Улалу. пост Ановили:

$\S$ 1. 1/ Постановления Революци-онн ого Комитета от 11-го августа за № 2 и 15 -го августа за № 3 о назначении Уполномоченным т. ЩЕГЛОВА подтвердить.

2/ Руководствуясь постановле-нием ВЦИК от $1 / \mathrm{VI}$ и постановлением Алтгубисполкома от 6/VI- с.г. за № 63, п. 6 о передаче всего аппарата ГорноАлтайского Уисполкома и его отделов Облревкому - ходатайствовать перед Сибревкомом и Алгубисполкомом о переводе всей Алтайской Поч.-Тел. Конторы, как центра Горно-Алтайского уезда, в село Улалу, оставив всех работников на занимаемых местах во главе с Заведывающим тов. CЕЛЕЗНЕВЫМ, которого утвердить Заведывающим Областной ПочтовоТелеграфной Конторой.

3/ Учитывая стремление Алгубнарсвязи оставление Области без надлежащего количества специалистовработников, признать необходимым окончательн ое вопроса о связи оставить открытым до выезда Предоблревкома в г. Барнаул и Н-Николаевск.

Тов. КУЗНЕЦОВУ переброску до выяснения не производи ть.

§ 2. С читаясь с занятостью крестьянства уборкой хлебов, переброску учреждений производить с 15 сентября, к какому сроку предложить всем Отделам и учреждениям быть готовыми к переезду. 
§ 3. Доклад т. ИВАНОВА о § 3 . Ввиду того, что захватываемое возврашении имушества и скота имушество и скот являются забираемого военчастями у населения в принадлежащими населению, момент освобождения районов от Революционный Комитет считает бандитов и считающего таковое как недопустимым признавать таковое как воен трофеи.

воентрофеи. Дабы сохранить крестьянское хозяйство и предотвратить бесконтрольное истребление крестьянского скота военчастями, ходатайствовать перед Сибревкомом о создании при действующих частях специальных комиссий под председательством Представителя Облревкома, которые должны учитывать все военные трофеи на месте и выявлять принадлежность имушества и скота, а если таковое принадлежит населению, хотя бы отбитое у бандитов. Если владельцы докажут, что скот и имушество было ограблено у населения, то возврашать таковое по принадлежности владельцам.

Подлинный подписали: Председатель ИВАНОВ

Секретарь МАЛКОВ

Верно: Секретарь Малков (подпись).

Источник: ГАНО. Ф. Р-1. Оп. 1. Д. 787. Л. 1-13об.

Список упоминаемых лиц:

1. Эйхе Р.И., советский партийный и государственный деятель. В 1925-1929 пред. Сиб. крайисполкома. 1929-1937 - 1-й секретарь Сибкрайкома. 10.193704.1938 - нарком земледелия СССР. 29.04.1938 арестован по обвинению в создании латышской фашистской организации. Осужден Военной Коллегией (ВК) Верх. суда СССР 02.02.1940 к ВМН. Расстрелян 04.02.1940.

2. Иванов (Меджит-Иванов) Н.Ф., советский работник. 1920-05.1923 председатель Ойротского уездного (с 08.1922 - обл.) ревкома. 05.1923-1924 - председатель Ойротского обл. исполкома. 1924-1937 - консул СССР в Монголии. 28.05.1937 арестован по обвинению в причастности к буржуазнонационалистической организации. Постановлением тройки УНКВД по ЗСК от 04.10.1937 приговорен к ВМН. Расстрелян.

3. Папардэ Л.А., партийный и советский работник; 1921-1922 - секретарь Ойротского укома РКП(б). 1922-1923 - зав. агит.-проп. отделом Алтайского губкома РКП(б). 1924 - зав. орготделом Ойротского обкома РКП(б). 10.1924-12.1928 - ответ. секретарь Ойротского обкома РКП(б). Позднее зав. отделом Сибкрайкома ВКП(б). В 1931-1932 - председатель Зап.-Сиб. 
краевой КК-РКИ. С 04.1934 - на партработе в Свердловске, затем в Смоленске. 01.1938 арестован по обвинению в контрреволюционной деятельности. 20.08.1938 приговорен к ВМН. Расстрелян 29.08.1938.

4. Чусов Г.И., 1920-1921 - зав. отделом и председатель Горно-Алтайского уездного комитета труда. 1922 - врид секретаря укома РКП(б). С 08.1922 зав. отделом труда Ойротского облревкома. С 10.1923 - зав. орготделом Ойротского обкома РКП(б). На 1961 проживал в Барнауле.

5. Гордиенко П.Я., в 1922-1923 - председатель Горно-Алтайского уездного исполкома и редактор газеты «Ойратский край». 03.1923-10.1924 - ответ. секретарь Ойротского обкома РКП(б). В 1930 - зам. председателя Ойротского облисполкома и 2-й секретарь обкома ВКП(б). 1930-11.1932 - 1й секретарь Ойротского обкома ВКП(б). Позднее - пред. ЗаП.-Сиб. краевого Совета профсоюзов, пред. Новосибирского горсовета. 20.11.1937 арестован по обвинению в контрреволюционной деятельности. Осужден 22.06.1938 ВК Верх. суда СССР к ВМН. Расстрелян в тот же день в Новосибирске.

6. Сары-Сеп Конзычаков Л.А., с 1921 - зам. зав., зав. отделом по делам национальностей Алтайского губисполкома. 08.-12.1922 - зав. отделом управления и зам. председателя ревкома Ойротской АО. В 1924 исключен из РКП(б) как «националист». В 1936 работал счетоводом в колхозе им. Розы Люксембург Старо-Бардинского р-на. 21.05.1937 арестован как «участник контрреволюционной националистической повстанческой организации». Постановлением тройки УНКВД по ЗСК от 01.10.1937 приговорен к ВМН. Расстрелян 14.10.1937.

7. Строев (Чагат-Строев) (Трепихин) П.А., с 08.1921 - член Ойротского облревкома. 1922 - член ВЦИК от Ойротской АО. Снят с должности в связи с конфликтом с руководителями облревкома и обвинениями в разжигании национальной вражды. Занимался литературной и журналистской работой в местных газетах. Создал первые литературные произведения на алтайском языке, стихи, алтайские буквари. На 1937 - секретарь сельсовета Чемальского аймака. Арестован по обвинению в контрреволюционной деятельности. Постановлением тройки УНКВД по ЗСК от 18.08.1937 приговорен к 10 годам ИТЛ.

8. Малков И.М., 1920-1922 - секретарь и инструктор Алтайского укома РКП(б). С 08.1922 - секретарь Ойротского облревкома (облисполкома). На 1941 - зав. мастерскими конторы «Крайлеспромснабсбыт» (Барнаул). 02.07.1941 арестован по обвинению в контрреволюционной деятельности. Решением Особого совещания при НКВД СССР от 23.05.1942 приговорен к 10 годам ИТЛ.

9. Алагызов (Алагыз-Мэркыт) И.С., 1920-1922 - зав. отделом народного образования, зав. отделом по делам национальностей уездного ревкома (Улала). 1923-1924 - зав. коммунальным отделом Ойротского облисполкома; пом. прокурора Ойротской АО. 09.1924-1930 - пред. Ойротского обл. исполкома. 1930-1931 - представитель Ойротской АО при ВЦИК. 1931-1937 - зав. отделом по делам национальностей Зап.-Сиб. крайисполкома. 19.05.1937 арестован по обвинению в причастности к буржуазно-националистической организации. Постановлением тройки УНКВД по ЗСК от 04.10.1937 приговорен к ВМН. Расстрелян 11.10.1937.

$$
* * *
$$

1. Сары-Сэп Конзычаков Л.А. Культурно-исторический очерк об алтайцах (к вопросу о выделении автономной области "Ойрат") // Сибирские огни. 1922. № 1.

2. Эдоков Л.М. Пять лет Ойротии (1922-1927). М., 1930. 
3. История Сибири. Том четвертый. Сибирь в период строительства социализма. Л., 1968.

4. Власов А.П. Образование Горно-Алтайской автономной области. // Доклады научной конференции. Ноябрь 1971. Томск, 1972.

5. Потапов Л.П. Очерки по истории Горно-Алтайской автономной области. Горно-Алтайск, 1973.

6. Демидов В.А. Октябрь и национальный вопрос в Сибири. 1917-1923 гг. Новосибирск, 1983.

7. Мамет Л.П. Ойротия. Горно-Алтайск, 1994.

8. Эдоков В.И. Возвращение мастера. Горно-Алтайск, 1994.

9. Демидов В.А. От Каракорума к автономии: пособие к спецкурсу. Новосибирск, 1994.

10. История Горного Алтая. В трех томах. Том второй. 1900-1945 гг. Бийск, 2000.

11. От уезда к республике. Сб-к архивных док-тов 1917-2001 гг. / Под ред. Д.И. Табаева, Е.П. Пак. ГорноАлтайск, 2001.

12. Русанов В.В. Пути национального самоопределения алтайского народа в первой четверти XX века. Автореф. дисс...к.и.н. Абакан, 2004.

13. Политическая история Горного Алтая и Г.И. Чорос-Гуркин. 1900-1940 гг. Горно-Алтайск, 2005.

14. Малчинов А.С. Конституционное развитие Алтая: от уезда к республике (государственно-правовые вопросы). М., 2006.

15. Сушко А.В. Процессы суверенизации народов Сибири в годы Гражданской войны. Омск, 2009.

16. Белозёрова М.В. К истории образования Ойротской автономной области (начало 1920-х гг.) // Вестник Томского государственного университета. № 308. 2008.

17. Нам И. В. Национальные меньшинства Сибири и Дальнего Востока на историческом переломе (1917-1922 гг.). Томск, 2009.

18. Екеева Н.М. История образования Горно-Алтайской (Ойротской) автономной области. / История и современность Республики Алтай. Материалы республиканской научно-исторической конференции. ГорноАлтайск, 2012.

19. Захарова Т.В. Очерки по социальной истории Ойротии (1917-1929 гг.). Монография. Горно-Алтайск, 2015.

20. Мамышева Е.П. Исторический опыт национально-государственного строительства в Южной Сибири в $1917-$ 1941 гг. Автореф. дисс...д.и.н. Улан-Удэ, 2017.

Томилов В.О., Грачева А.А., Малкина А.С., Павлычев А.В., Кадомцева А.В. Влияние гражданского кодекса Наполеона Бонапарта на развитие Франции и европейского общества в целом

ФГБОУ ВО "Приволжский исследовательский медииинский университет" Министерства здравоохранения Российской Федеращии

(Россия, Нижний Новгород)

doi: 10.18411/trnio-10-2021-160

\section{Аннотация}

Статья посвящена рассмотрению особого вклада гражданского кодекса Наполеона Бонапарта, принятого в 1804 году. Автор подчеркивает, что по настоящее время используются некоторые статьи кодекса Наполеона. В нем были заложены основы свободы собственности и личных свобод человека, повлиявшие не только на Францию, но и на законодательство всей Европы.

Ключевые слова: Наполеон, кодекс, гражданское право.

\section{Abstract}

The article is devoted to the consideration of the special contribution of the civil code of Napoleon Bonaparte, adopted in 1804. The author emphasizes that some articles of the Code of Napoleon are still used. It laid the foundations for the freedom of property and personal freedoms of a person, which influenced not only France, but also the legislation of the whole of Europe.

Keywords: Napoleon, code, civil law.

На данный момент французский Гражданский Кодекс 1804 года (Кодекс Наполеона) можно считать одним из наиболее совершенных памятников права за историю человечества. В нем были заложены основы свободы собственности и личных свобод человека, повлиявшие не только на Францию, но и на законодательство всей Европы. Некоторые статьи данного Кодекса действуют во Франции в настоящее время в неизмененном виде. 